\title{
The Study of Early Selection Method through Vigor and Viability Parameter in Citrus amblycarpa(Hassk) under Salinity and Drought Stress Condition
}

\author{
Anggi Nindita*, Choirul Umam, Siti Fatimah, and Faiza Suwarno \\ Department of Agronomy and Horticulture, Faculty of Agriculture, Bogor Agricultural University. \\ Dramaga Campus, Bogor 16680, Indonesia \\ *Corresponding author: angginindita@apps.ipb.ac.id
}

\section{ARTICLE HISTORY}

Received: 5 July 2018

Revised: 28 July 2018

Accepted: 7 September 2018

\section{KEYWORDS}

First count

Germination media

Limau Lime

NaCl, PEG

Second count

\begin{abstract}
The study was aimed to obtain information regarding the early selection method of Limau lime under saline and drought condition including the proper method for seed extraction, observation period in germination testing, and type of germination media. The experiment was conducted from March 2015 to January 2016 at the Laboratory of Seed Science and Technology, Department of Agronomy and Horticulture, Faculty of Agriculture, Bogor Agricultural University. It consisted of four main experiments. The first experiment was the extraction method on Limaulime seed using distilled water, ash from the husk, talcum powder, and $\mathrm{HCl} 1 \%$. The second experiment was germination testing of lime seed using three media i.e. sand, the combination of sand: soil (1:1) (v:v), and towel tissue. The third experiment has tested the vigor of Limau lime seeds in different saline conditions by using $\mathrm{NaCl}$, i.e. 1500 ppm, 3000 ppm, and $4500 \mathrm{ppm}$. The fourth experiment, tested the vigor of Limau lime seeds in drought stress condition using PEG 6000, i.e. 0, - 0.75 bar, -1.5 bar, and -2.25 bar. The result of the first experiment showed that the treatments had no significantly different effect on all variables observed except for the seed moisture content. The second experiment revealed that the best germination media was elucidated from sand treatment and sand: soil (1:1) with the first and the second count at 20th and 29th day respectively. The result of the third and four experiment elucidated that the higher concentration of $\mathrm{NaCl}$ (Salinity stress condition) or PEG 6000 (drought stress condition), the smaller the germination percentage of Limau Lime's seeds.
\end{abstract}

This is an open access article under the CC-BY-SA license.

\section{INTRODUCTION}

The Limau is one of the indigenous fruits in Indonesia. Indonesia is a tropical country where various types of citrus are often found and cultivated from the lowlands to the highlands. Furthermore, several types of citrus have become important flagship commodity in regional and national trade (Chaireni, 2008). Indonesia has a very large area and a lot of lands that has not been used optimally. Moreover, it becomes a challenge to provide eligible and suitable land for fruit development in Indonesia. Some lands which have a high level of suitability have been used for other activities (Poerwanto, 2003).

Generally, Limau or lime fruit is used as a flavoring dish. The use of lime in various cuisines describes that citrus fruit has good market potential but lime farming in Indonesia is still cultivated traditionally with low production. Another factor that can cause the production of low lime oranges is due to low seed quality.

Recently, several advanced types of research have been conducted in order to improve the quality of citrus in environmental, agricultural and biotechnology to improve citrus crop production. Recent research also conducted in the level of chromosomal markers to distinguish accessions of citrus particularly to describe karyotype of C. amblycarpa (Moraes, et al., 2007). Further research regarding in metabolomics trait stated that untargeted GCMS analysis elucidated the potential of C. amblycarpa to produce functional compounds as the identified metabolites within leaf and fruit of Limau (Budiarto, et al., 2017).

Further study is needed to develop a more effective technique for seed extraction, germination ability for improving crop production and determining selection method for abiotic stress. According to Samira (1999), one of the initial stages in obtaining high-quality seeds is 
the right way to extract seeds. Another factor that influences seed germination is growth media of germination and seed vigor. The use of germination media will show different results in different commodities so that the suitable use of germination media is needed to help to improve the viability of the seeds planted.

Multiple abiotic stresses are assumed occurring with drought and salinity in citrus (Syvertsen and Sanchez, 2014). Several types of research published related to the salt condition, drought condition and its impact that tested in several genotypes of citrus (Yahmed et al., 2015; Sousa et al., 2016; Nimbolkar et al., 2016). According to Sadjad (1993), to detect seed vigor against suboptimum conditions (drought and salinity) can be done in a greenhouse or laboratory by testing the growth of seeds on media that can be controlled and more practical as on paper, sand or soil. Germination testing protocol of citrus was stated in ISTA (2014) and the information regarding C. amblycarpa. Drought stress condition treatment conducted through Polyethylene glycol (PEG) application and salinity stress condition treatment provided from $\mathrm{NaCl}$ salt application in different concentration. The study was aimed to obtain information regarding the early selection method of Limau lime under saline and drought condition including the proper method for seed extraction, observation period in germination testing and type of germination media..

\section{MATERIALS AND METHODS}

The study was conducted from March 2015 to January 2016. Seed viability and vigor analysis were conducted at the laboratory of Seed Science and Technology, Department of Agronomy and Horticulture, Bogor Agricultural University. Limau Lime (Citrus amblycarpa (Hassk.)) seed was obtained from Plantation in Bogor, Indonesia.

\subsection{Amblycarpa Seed Extraction Method}

The first experiment was arranged in randomized complete experimental design with one factor which had four replications. Level of treatments was using distilled water, ash from husk, talcum powder, and $\mathrm{HCl}$ 1\%. Thirty seed were tested in each experimental unit and growth in eco-germination chamber IPB 72-1 for 30 days. Parameters observed were germination percentage, maximum growth potency, vigor index, speed of seed growth.

\subsection{Amblycarpa Seed Vigor in Salinity Stress Condition}

The second experiment was arranged in randomized complete block design with one factor and four replications. $\mathrm{NaCl}$ treatment applied to perform salinity stress condition in four concentrations: 0 ppm, $1500 \mathrm{ppm}$, $3000 \mathrm{ppm}$, and $4500 \mathrm{ppm}$.

\subsection{C. amblycarpa Seed Vigor in Drought Stress Condition}

The third experiment was arranged in randomized block design with one factor and four replications. PEG-6000 was applied to perform drought stress condition in four levels of concentration: 0 bar, -0.75 bar, -1.5 bar, and -2.25 bar. The PEG 6000 concentration was determined from Michel and Kaufman (1973) as following:

$\Psi_{\mathrm{s}}=-\left(1.18 \times 10^{-2}\right) \mathrm{C}-\left(1.18 \times 10^{-4}\right) \mathrm{C}^{2}+\left(2.67 \times 10^{-4}\right) \mathrm{CT}+$ $\left(8.39 \times 10^{-7}\right) \mathrm{C}^{2} \mathrm{~T}$

\subsection{Statistical Data Analysis}

Data of Analysis of Variance (ANOVA) and means comparison was computed by R software. DMRT test was used to analyze significant different in different level of treatment with probability $5 \%$.

\section{RESULTS AND DISCUSSIONS}

\subsection{Seed Extraction Method}

Mean values from the effect of the seed extraction treatment to parameter of moisture content, germination percentage, normal seedling dry weight, maximum growth potency, and vigor index described on Table 1.

Table 1. Mean Values of Viability and Vigor from Extraction Method Treatment

\begin{tabular}{|c|c|c|c|c|c|}
\hline Treatments & $\mathrm{MC}(\%)$ & GP (\%) & NSDW (g) & MGP (\%) & VI (\%) \\
\hline Aquadestillate & $22.71 \mathrm{a}$ & 82 & 0.39 & 95 & 27 \\
\hline Ash & $16.50 \mathrm{~b}$ & 87 & 0.52 & 98 & 31 \\
\hline Talc Powder & $16.47 \mathrm{~b}$ & 90 & 0.46 & 97 & 34 \\
\hline $\mathrm{HCl} 1 \%$ & $22.33 \mathrm{a}$ & 86 & 0.46 & 95 & 38 \\
\hline
\end{tabular}

Note: Mean followed by the same letters are not significantly different based on the DMRT test at 0.05 level; MC = Moisture content; GP = germination percentage; NSDW = normal seedling dry weight; $M G P=$ maximum growth potency; VI = Vigor Index

The mean values from viability and vigor parametersshowed insignificant different in all variables except the moisture content. The moisture content value from distilled water and HCL 1\% treatment had higher values than other treatments. The seed immersion treatment in the extraction method using distilled water and $\mathrm{HCl} 1 \%$ was predicted involved to the water content addition into the seed (Table 1). According to Raganathaet al.(2014), seed has hygroscopic character, which is easy to absorb water vapor from the surrounding environment up to balance condition between seed and its environment. 
C. amblycarpa is polyembrionic, which is there are more than one germination from one seed planted. In this experiment, only one seed selected to be the best from one seed. According to germination percentage, the treatment of extraction method has beenelucidated that the result were not significantly different and estimated to be having equal result. Nevertheless, talc powder as extraction method provide the most optimum result of $90 \%$ (Table 1).

\subsection{Determination of C. amblycarpa Germination}

\section{Percentage Period}

\section{C. amblycarpa Germination Percentage First count observation}

According to Sadjad (1994), the determination of the first count period is related to the increased number of normal germination percentage that occurs daily during estimation to a maximum percentage. The second observation continued to determine which period that the seed reach maximum accumulation of germination percentage. In other words, the second count period observation occurred on the day of achieving the maximum accumulation of germination percentage. The graph for determining the period of germination percentage first-count observation through combination media sand: soil (1:1) and towel tissue is presented in Figure 1.
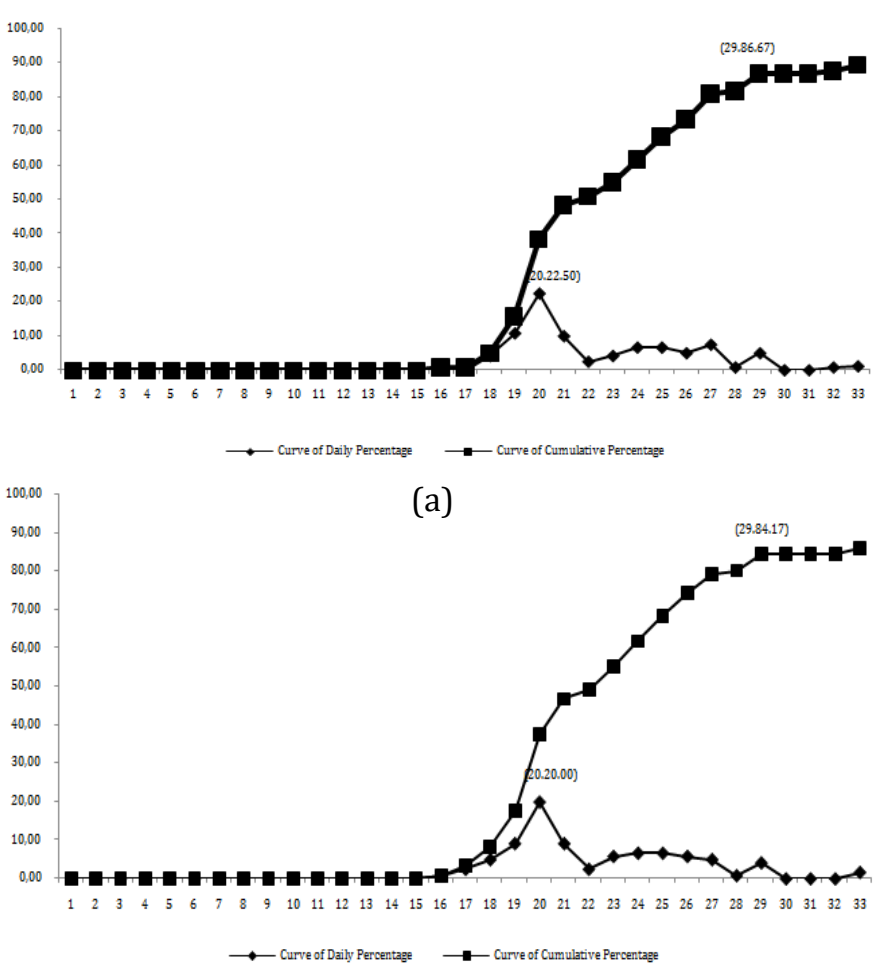

(b)

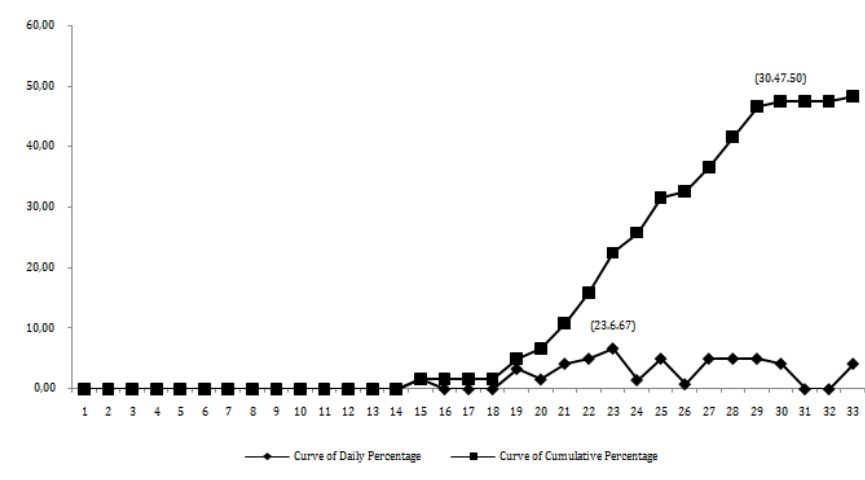

(c)

Figure 1. Graph of Lime Seed Germination Period in Three Different Media: (a) Media of Sand; (b) Media of Sand: Soil (1:1); (c) Media of Tissue Towel

Based on Figure 1, the first count estimation on media of sand was day-20 with daily maximum germination percentage was $22.50 \%$ and second count observation at the day of 29 with cumulative percentage is $86.67 \%$. Media combination of sand: soil resulted first count observation period at the day of 20 with the daily maximum germination percentage is $20 \%$. The second count was observed on the day of 29 with cumulative germination percentage was $84.17 \%$. The first and second count in media treatment of towel tissue was a day of 23 and 30 respectively. The daily maximum germination percentage was $6.67 \%$ and cumulative germination percentage was $47.50 \%$..

\section{Media of Lime Seed Germination}

Mean values of germination percentage, maximum growth potency, vigor index, and germination velocity from media treatment were given in Table 2. Table 2 stated that media treatment of sand and combination of sand:soil (1:1) significantly showed higher viability compared to towel tissue treatment. Media of sand possessed the most optimum result in viability parameter.

The result of research done by Sudomo(2012) showed that growth media from sand has given the best germination percentage compared to others growth germination media from soil, sawdust, and cocopeat. Growth media of sand possessed high germination percentage due to porosity and aeration that sprout needed to grow. Similar result was given in this research. The sand as germination media showed the most optimum result in all variables of parameters: germination percentage (86.67\%), maximum growth potential (95.83\%), index vigor (38.33\%), and germination velocity (3.967 \% etmal-1) (Table 2 ).

Table 2. Mean Value of Viability and Vigor from Media Type Treatment

\begin{tabular}{lcccc}
\hline \multicolumn{1}{c}{ Treatment } & GP (\%) & MGP (\%) & VI (\%) & GV (\% etmal $\left.{ }^{-1}\right)$ \\
\hline Sand & $86.67^{\mathrm{a}}$ & 95.83 & 38.33 & $3.967^{\mathrm{a}}$ \\
Sand:Soil (1:1) & $84.17^{\mathrm{a}}$ & 95.00 & 37.50 & $3.890^{\mathrm{a}}$ \\
Towel Tissue & $47.50^{\mathrm{a}}$ & 93.33 & 22.50 & $2.020^{\mathrm{b}}$ \\
\hline
\end{tabular}

Note : Means followed by the same letter are not significantly different based on the DMRT test at 0.05 level; GP = germination percentage; MGP = maximum germination potency; VI = vigor index; $G V=$ germination velocity 


\section{C. amblycarpaSeed Viability and Vigor under Salinity Stress Condition}

The statistical data analysis indicated that mean values of vigor index, normal seedling dry weight, and rootlength in every level of treatment exhibited different response. Mean values were given in Table 3.

Table 3. Mean Value of Lime Seed Vigor under Salinity Stress Condition

\begin{tabular}{|c|c|c|c|}
\hline \multirow[t]{2}{*}{ NaCl Treatment (ppm) } & \multicolumn{3}{|c|}{ Parameter } \\
\hline & Vigor Index (\%) & NSDW (mg) & Root Length $(\mathrm{cm})$ \\
\hline 0 (Control) & $51^{\mathrm{a}}$ & $4.85^{\mathrm{a}}$ & 10.25 \\
\hline 1500 & $26^{b}$ & $2.65^{a}$ & 9.13 \\
\hline 3000 & $12^{c}$ & $2.60^{\mathrm{a}}$ & 10.08 \\
\hline 4500 & $8^{c}$ & $1.88^{\mathrm{b}}$ & 9.48 \\
\hline
\end{tabular}

Note : Mean followed by the same letters are not significantly different based on the DMRT test at 0.05 level; NSDW = normal seedling dry weight

One of the characteristics of high-quality seeds was high vigor. The treatment of salinity stress condition exhibited significantly different result in all vigor and viability parameters of Lime seed. The decrease of germination ability can be associated with the prevention of water uptake due to salinity stress condition. Furthermore, another causation is due to toxic effects of $\mathrm{Na}+$ and $\mathrm{Cl}-$ on the germination process (Khajeh-hosseini et al., 2003). This may cause the process of lime seed germination of lime seed obstructed. The result of this study is in accordance with Rahmawati (2006).It mentioned that the effect of salinity stress condition can further reduce rice seed germination due to turgor pressure.

The viability of seed is the vitality or life force of seeds which can be demonstrated through the symptoms of seed metabolism and growth symptoms. In seed testing, this viability indicated and measure through germination percentage and normal seedling dry weight (Sadjad, 1994). A number of germination percentage of Lime seed was given in Figure 2.

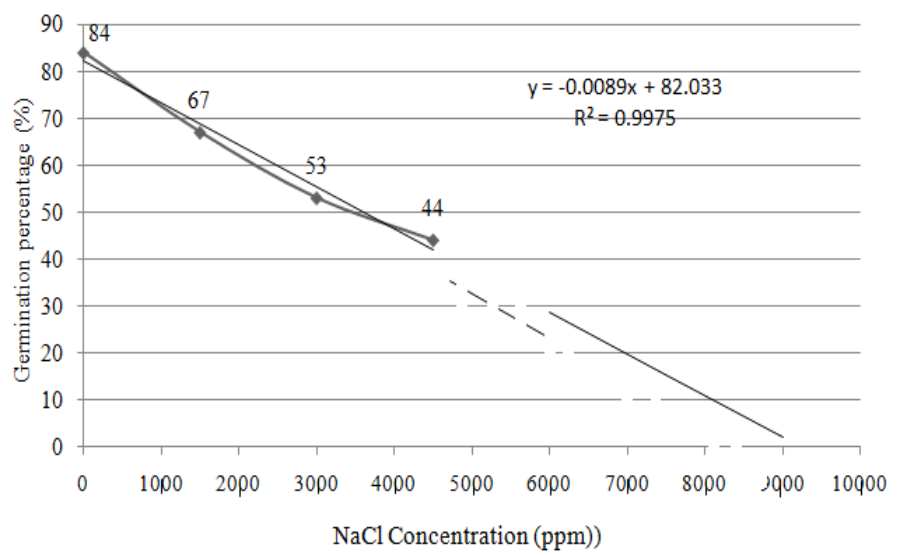

Figure 2. The Effect of Salinity Stress Condition on Lime's Seed Germination Percentage

The increasing of $\mathrm{NaCl}$ concentration will cause the germination percentage of Lime seed to decrease. At 3000 ppm of $\mathrm{NaCl}$ concentration, the germination only 53\% survived. Through this research, linear equation was defined i.e. $\mathrm{y}=-0.0089 \mathrm{x}+82.033$, with number of $\mathrm{R}^{2}=$ 0.9975. Naseriet al. (2012) reported that barley seed germination decreases within increasing levels of salinity, the decrease of seed germination was significant at a higher level of salinity. Syvertsen and Sanchez (2014) stated that in some conditions, salt stress condition can provide advantages to plants. The decreasing number of germination percentage was linear to the decrease of normal seedling dry weight of lime seeds. Salinity stress inhibits amylase activity at the germination stage which function as energy during germination (Hua-Longet al., 2014).

Kusmiyati et al. (2009) found that the form of plant adaptation mechanism to salinity stress condition was the morphological and physiological mechanism. The simple mechanism to detect plant response was through the morphological mechanism which was the morphological changes in the organs of plant i.e. roots, stem and leaves. The experiment results elucidated that there was no significantly different effect on the length of Lime's seed root. The control $(0 \mathrm{ppm} \mathrm{NaCl})$ showed the longest length of the root $(10.25 \mathrm{~cm})$ and varying response regarding other treatments although not significantly different (Table 3). This is contrary to Rahmawati (2006) finding that salinity stress condition was able to inhibit root growth. Rachmawati and Nasir (2014) research result reported that the increase of $\mathrm{NaCl}$ concentration significantly decreased root length of all green bean varieties.

\section{C. amblycarpaSeed Viability and Vigor under Drought Stress Condition}

The statistical data analysis indicated that mean values of vigor index, normal seedling dry weight, and root length in every level of treatment possessed different response in drought stress condition. Mean values were given in Table 4.

The value of the vigor index is always lower than the value of the germinating power but is closer to the growth of seeds in the field (Sadjad, 1994). The treatment of drought stress has a very significant effect on the vigor index of lime seeds. The higher the level of drought stress, the lower the vigor index value of lime seeds. The germination process is in desperate need of water, therefore the role of water is very important (Aryati,2011). PEG has the property of inhibiting water absorption by plant cells, so that plants are difficult to 
germinate (Shintarika et al. ,2013). The low value of the vigor index is thought to be caused by the drought stress of citrus seeds experiencing inhibition of water absorption.

Increased osmotic pressure results in a decrease in the percentage of germination and the dry weight of normal sprouts of lime seeds.
The power value of germinating lime seeds was presented in Figure 3. From these data obtained a linear equation of the relationship between PEG 6000 treatment on the germination power of lime orange seeds, $y=26.333 x+$ 92.751; with a value of $\mathrm{R}^{2}=0.9997$ (Figure 3 ).

Table 4. Mean Value of Lime Seed Vigor under Drought Stress Condition

\begin{tabular}{ccccc}
\hline $\begin{array}{c}\text { PEG 6000 } \\
\text { (bar) }\end{array}$ & \multicolumn{3}{c}{ Parameter } \\
\cline { 2 - 5 } & Vigor Index (\%) & NSDW (mg) & Root Length (cm) & $\begin{array}{c}\text { Accretion number of root length } \\
(\mathrm{cm})\end{array}$ \\
\hline 0 (Control) & $60.00^{\mathrm{a}}$ & $6.38^{\mathrm{a}}$ & $9.39^{\mathrm{b}}$ & - \\
-0.75 & $35.00^{\mathrm{b}}$ & $4.45^{\mathrm{b}}$ & $9.83^{\mathrm{b}}$ & 0.44 \\
-1.5 & $20.84^{\mathrm{c}}$ & $3.93^{\mathrm{b}}$ & $11.13^{\mathrm{ab}}$ & 1.30 \\
-2.25 & $6.67^{\mathrm{d}}$ & $1.85^{\mathrm{c}}$ & $12.74^{\mathrm{a}}$ & 1.61 \\
\hline
\end{tabular}

Note : Mean followed by the same letter are not significantly different based on the DMRT test at 0.05 level; NSDW = normal seedling dry weight

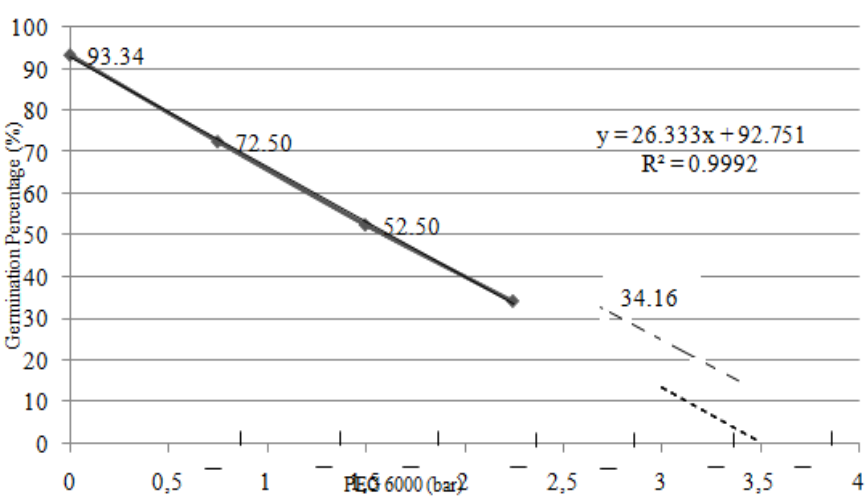

The results of this study were in line with Keshtibanet al. (2015) that drought stress using PEG 6000 had a significant effect on seed germination due to more negative osmotic potential. This decrease was also accompanied by a decrease in the normal dry weight of lime seeds. Normal sprouting dry weight gradually decreases with increasing stress levels. This was in line with research conducted by Cholidet al. (2014) on castor plants. Drought stress can inhibit the growth of jatrophaplants,it can be seen from the decreasing values of the variable number of live plants and dry weight. The decline in variable values when gripped by drought showed that jatropha plants were trying to adapt to drought stress so that plants can survive and maintain metabolism.

At drought condition, plants will adapt to life. Root as the main plant organ which has main function in absorbing water will respond to keep getting water from the environment. The mean values of root length when experiencing drought stress using PEG-6000 had been presented in Table 4. Roots of lime seedlings experienced a long increase in line with the increase of PEG-6000 level. The root length increase was calculated based on the average seeds that have grown normally.

The results of this study were in agreement with research by Cholidet al. (2014). It stated that when there was stress drought, the jatropha plant would extend the roots. Another study stated that an increase in PEG concentration resulted in a decrease in the average root length of citrus plants in vitro (Adiyanti, 2013) and a decrease in the average root length of rice plants (Aryati, 2011). The decrease in root growth may be due to low osmotic potential and a decrease in wall length and cellular expansion (Mohammadkhani and Heidari, 2008).

\section{CONCLUSION}

Extraction method of Limau seeds (Citrus amblycarpa (Hassk. Ochse) using distilled water, ash, talcum powderand $1 \%$ HClrevealed that the results were not significantly different based on germination percentage result that is $82-90 \%$. The first and second counts on sand and sand: soil (1: 1) media resulted in the $20^{\text {th }}$ and $29^{\text {th }}$ days, while towel tissue media resulted in the $23 \mathrm{rd}$ and $30^{\text {th }}$ days. Limauseeds grown on sand germination media and a mixture of sand: soil (1: 1) was significantly higher in viability than towel tissue media except for maximum growth potential variables and vigor index. The treatment of saline stress and drought stress showed that the higher the stress level given, the vigor index, the lower germination percentage and normal seedling dry weight of lime seeds. The root length measurement could not be used to assess the durability of Limauseeds undersalinity stress condition. The condition of drought stress indicated that the root length value of the growing seed increases with increasing drought stress.

\section{REFERENCES}

Adiyanti, D.R. 2013. Seleksi kekeringan pada beberapa varietas batang bawah jeruk secara in vitro. [Skripsi]. Institut Pertanian Bogor. Bogor.

Aryati,V. 2011. Metode pengusangan cepatter control untuk mengidentifikasi secara dini geno tipe padigogo (Oryza sativa L.) toleran kekeringan. [Skripsi. Institut Pertanian Bogor. Bogor

Budiarto, R., R. Poerwanto, E. Santosa, D. Efendi. 2017. The potential of limau (Citrus amblycarpa Hassk. Ochese) as a functional food and ornamental mini tree based on metabolomics and morphological approaches. J. of Tropical Crop Science.4:2.

Chaireni, M. 2008. Teknik identifikasi varietas jeruk. J. Iptek Hortikultura. 4(5) 6-12.

Cholid, M., Hariyadi, S. Susanto, Djumali, B.S. Purwoko. 2014. Pemilihan batang bawah jarak pagar (Jatrop hacurcasLinn.) toleran terhadap cekaman kekeringan. Jur.Littri. 20(1): 45-56.

Hua-long, L., S. Han-jing, W. Jing-guo, L. Yang, Z. De-tang, Z. Hong-wei. 2014. Effect of seed soaking with exogenous proline on seed 
germination of rice under salt stress. Journal of Northeast Agricultural University. 21(3): 1-6.

[ISTA] International Seed Testing Association. 2014. International Rules of Seed Testing. The International Seed Testing Association (ISTA), Bassersdorf, CH-Switzerland.

Khajeh-hosseini, M., A.A. Powell,I.J. Bingham. 2003. The interaction between salinity stress and seedvigor during germination of soybean seed. Seed Science and Technology. 31(3): 715-725.

Keshtiban, R.K., V. Carvani, M. Imandar. 2015. Effects of salinity stress and drought due to different concentrations of sodium chloride and polyethylene glycol 6000 on germination and seedling growth characteristics of pinto bean (Phaseolus vulgaris L.). Advances in Environmental Biology. 9(5): 229-235.

Kusmiyati, F.,E.D. Purbajanti,B.A. Kristanto. 2009. Karakterfisiologis, pertumbuhan dan produksi legume pakan pada kondisi salin. Seminar Nasional Kebangkitan Peternakan. Semarang.

Michel B. E., M.R. Kaufman. 1973. The osmotic potential of polyethylene glycol 6000. Plant Pysiol. 51: 914-916.

Mohammadkhani, N., R. Heidari. 2008. Drought induced accumulation of soluble sugars and proline in two maize varieties.J. World Appl. Sci.3(3): 448-453.

Moraes, A. P., R. R. Lemos, A. C. Brasileiro-Vidal, W. S. S. Filho, M. Gurra. 2017. Chromosomal masrkers distinguish hybrids and non-hybrids accessions of mandarin. Cytogenet genome Res. 119: 275-281

Naseri, R.,T. Emami, A. Mirzael, A. Soleymanifard. 2012. Effect of salinity (sodium chloride) on germination and seedling growth of barley (HordeumvulgareL.) cultivar. Intl J Agri Crop Sci.13(4): 911-917.

Nimbolkar, P.K., B. Shiva, A. K. Rai. 2016. Rootstock breeding for abiotic stress tolerance in fruit crops. J. of Agriculture, Environmental, and Biotechnology. 9(3):375-380

Poerwanto, R. 2003. Peran Manajemen Budidaya Tanaman dalam Peningkatan Ketersediaan dan Mutu Buah-Buahan. IPB Press, Bogor.

Rachmawati, S.J., M. Nasir. 2014. Pertumbuhan Vignaradiata (L.) Wilczek pada tingkat salinitas $\mathrm{NaCl}$ yang berbeda. Agronomika. 9(2): 223-234.

Raganatha, I.N., I.G.N. Raka, I.K. Siadi. 2014. Daya simpan benihtomat (Lycopersicumesculentum Mill.) hasil beberapa teknik ekstraksi. J Agroteknologi Tropika. 3 (3): 183-190.

Rahmawati, S. 2006. Status perkembangan dan perbaikan genetic padi menggunakan teknik transformasi Agrobacterium. Agro Biogen. 2: 364-375.

Sadjad, S. 1993. Dari Benih Kepada Benih. PT Grasindo, Jakarta.

Sadjad, S. 1994. Kuantifikasi Metabolisme Benih. PT. Gramedia Widiasarana Indonesia, Jakarta.

Samira, D. 1999. Pengaruh cara ekstraksi, suhu penyimpan dan periode simpan terhadap viabilitas benih jeruk besar (Citrus maxima Meer) [Skripsi]. Institut Pertanian Bogor. Bogor.

Shintarika, F., F.C. Suwarno, Suwarno. 2013. Pengujian vigor daya simpan dan vigor terhadap kekeringan pada benih padi gogo dan padi sawah. Bul. Agrohorti. 1(1): 67-71.

Sousa, J. R. M., H. R. Gheyi, M.E.B. Brito, D.A. Xavier, G. F. Furtado. 2016. Impact of saline conditions and nitrogen fertilization on citrus production and gas exchanges. Rev. caatinga. 29(2):415-424.

Sudomo, A. 2012.Perkecambahan Benih Sengon (Falcatarismuluccana (Miq.) Barnerby\& J. W. Grimes) Pada 4 Jenis Media.hlm 37-42.Seminar Nasional Penelitian dan PKM: Sains Teknologi dan Ilmu Kesehatan (SNaPP). Bandung, 13-14 November 2012.

Syvertsen, J.P., F.G. Sanchez. 2014. Multiple abiotic stresses occuring with salinity stress in citrus. Environmental and Experimental Botany.103: 128-137.

Yahmed, J. B., P. Novillo, A. Garcia-Lor, A. Salvador, M. B. Mimoun, F. Luro, M. Talon, P. Ollitrault, R. Morilon. 2015. Salt tolerance traits revealed in mandarins (Citrus reticulana Blanco) are mainly related to root-to-root $\mathrm{Cl}^{-}$translocation limitation and leaf detoxification processes. Scientia Horticulturae. 191: 90-100. 